\title{
Economic Structure and Aggregate Accounts
}

his chapter describes the structural features that, in our view, distinguish most developing countries from the textbook industrial-country model, and provides an overview of some general analytical features of developingcountry macroeconomic models. It takes a model-based perspective, focusing on the general structure of macroeconomic models for developing countries, including the accounting framework, the level of commodity disaggregation, and the particular role of labor markets. Chapter 2 will focus on specific components of macroeconomic models, examining evidence on the properties of private behavioral functions in developing nations.

This chapter is divided into four sections. Section 1.1 identifies the distinctive aspects of development macroeconomics. It also documents a range of regularities in macroeconomic fluctuations for developing countries. Section 1.2 sets out a general accounting framework consisting essentially of budget constraints for each type of agent typically appearing in a developing-country macroeconomic model, and defines several concepts that will prove useful later on. In Section 1.3, we consider how economic structure can be imposed on these accounting relationships by reviewing three alternative approaches to commodity disaggregation in an open economy: the Mundell-Fleming model, the "dependent economy" model, and a three-good structure distinguishing exportables, importables, and nontraded goods. Almost all macroeconomic models for developing countries rely on some variant of one of these approaches. Each of these three production structures is analyzed in both classical and Keynesian modes.

Section 1.4 looks at the labor market, a market that plays a central analytical role in all macroeconomic models, and the functioning of which is widely accepted to depend on country-specific institutional factors, both in the industrial- and developing-country contexts. As emphasized in Section 1.3, labor markets play a key role in determining the properties of an economy's short-run aggregate supply 
(c) Copyright, Princeton University Press. No part of this book may be distributed, posted, or reproduced in any form by digital or mechanical means without prior written permission of the publisher.

function. Accordingly, in Section 1.4 we examine the structural features of labor markets in developing nations. We focus on the short-run implications of these features, emphasizing the role of wage rigidity and the nature of labor market segmentation.

\section{Economic Structure and Macroeconomics}

The structural characteristics that differentiate a "representative" developing economy from the textbook industrial-country model cover a wide spectrum, spanning most of the standard components of a macroeconomic model. Many of these features are not shared by all developing countries, and some may be found among industrial countries as well. Nevertheless, we will provide evidence in this section that the features described below_all of which can be readily recognized as affecting macroeconomic behavior-systematically differentiate developing countries as a group from the standard textbook representation of an industrial-country economy. They include the nature of openness to trade with the rest of the world in both commodities and assets, the nature of financial markets, the characteristics of fiscal institutions and the government budget, the properties of the economy's supply function, the degree of income inequality, the stability of policy regimes, and the degree of macroeconomic volatility.

\subsection{Openness to Trade in Goods and Assets}

1. Developing economies, like small industrial countries, tend to be much more open to trade in goods and services than are the major industrial countries.

A standard measure of openness is the trade share, that is, the sum of the shares of exports and imports in GDP. By this measure, developing nations tend to be substantially more open than the major industrial countries. ${ }^{1}$ Openness to this extent, of course, limits at the outset the applicability of the closed-economy textbook industrial-country model to the developing-country context. Very few developing nations can even approximately be described as closed economies by this measure.

2. Developing countries typically have little control over the prices of the goods they export and import-that is, they typically face exogenous terms of trade.

This characteristic tends to distinguish developing countries even from small industrial countries. The exogeneity of the terms of trade for developing economies

\footnotetext{
${ }^{1}$ This group consists of Canada, France, Germany, Italy, Japan, the United Kingdom, and the United States. It should be noted that the degree of openness of the smaller industrial countries (such as Belgium) is typically much higher.
} 
(c) Copyright, Princeton University Press. No part of this book may be distributed, posted, or reproduced in any form by digital or mechanical means without prior written permission of the publisher.

is suggested both by their small share in the world economy and by the composition of their exports.

Very few developing countries account for a significant portion of the world market even for the commodities in which their exports are heavily specialized. Moreover, various studies confirm that, with limited exceptions for particular goods, these countries continue to have limited individual influence over the prices at which they buy and sell. Exogenous terms of trade call into question the usefulness, for the analysis of many macroeconomic policy issues in developing nations, of the openeconomy model that continues to be widely used in the industrial-country context, the Mundell-Fleming model. This model assumes endogenous terms-of-trade determination, with the domestic economy completely specialized in the production of a good over which it exerts significant market power. Instead, the production structure most suitable for the analysis of developing-country macroeconomic phenomena is likely to be the Salter-Swan "dependent economy" model or (given that terms-oftrade changes tend to be very important for such countries) a three-good model consisting of exportables, importables, and nontraded goods. Such a production structure permits a distinction to be drawn between the exogenous terms of trade and an endogenous real exchange rate, which is the central intratemporal macroeconomic relative price in these economies.

The importance for many developing nations of primary-commodity exports with exogenously determined prices accounts for an important source of macroeconomic instability in these countries. Prices of primary commodities tend to fluctuate quite sharply. Consequently, developing countries have faced highly unstable terms of trade at various times over the past two decades, with large asymmetric effects; for instance, in a study of the behavior of the real prices of thirty-six world commodities over the period 1957-1999, Cashin et al. (2002) found that price slumps typically last a lot longer than price booms. ${ }^{2}$ Episodes of drastic changes in the terms of trade for these countries have often been dominated by changes in oil prices, but at times nonfuel commodities also undergo sharp fluctuations in price. Coupled with the relatively large share of exports and imports in domestic economic activity, such fluctuations in export prices represent substantial exogenous changes in national income from one year to the next, and constitute an important source of macroeconomic volatility for such countries.

\section{The extent of external trade in assets has tended to be more limited in developing than in industrial countries, though this situation has recently begun to change in dramatic fashion for an important group of developing economies.}

\footnotetext{
${ }^{2}$ There is, however, continuous debate on whether there has been a secular deterioration in primary-commodity prices relative to prices of manufactured goods-the so-called Prebisch-Singer thesis. For alternative views on this issue, see Bleaney and Greenaway (1993b) and Reinhart and Wickham (1994).
} 
(c) Copyright, Princeton University Press. No part of this book may be distributed, posted, or reproduced in any form by digital or mechanical means without prior written permission of the publisher.

Perfect capital mobility is often used as the standard textbook assumption for industrial countries. In developing countries, capital controls have long been the rule, and although their effectiveness is questioned, the degree of capital mobility that characterizes economies that do not retain such restrictions remains far less than is assumed in textbook industrial-country models. Thus, unlike standard macroeconomic modeling for industrial countries, in the developing-country case the assumption of perfect capital mobility is generally inappropriate. Evidence on this issue is discussed in Chapter 13 and used in Chapters 6 and 10 to formulate appropriate models of the monetary transmission process and for the analysis of stabilization policies in developing countries.

4. Greater integration with international financial markets exposes many middle-income countries to abrupt reversals in capital flows, which exacerbate macroeconomic volatility.

For many developing countries, a large stock of gross external debt presents important macroeconomic challenges. Among highly indebted low-income countries, the problem emerged essentially because of borrowing by the government. The existence of such debt therefore has important implications for the level and composition of public expenditure. But among countries that have recently become integrated with international capital markets, external debt has tended to be incurred by the private sector. In this context, the policy challenges involve coping with potential macroeconomic overheating associated with a sudden inflow of capital, as well as with vulnerability to macroeconomic volatility induced by abrupt reversals in capital flows. As suggested by Caballero (2000), possible factors behind the high degree of volatility experienced by many middle-income developing countries are greater, but still weak, links with international financial markets (which limit the ability to borrow and lend to smooth shocks) and insufficiently developed domestic financial systems (which limit the speed of resource reallocation following an adverse shock and may magnify contractions in output).

\section{2 - Exchange-Rate Management}

5. In contrast to the major industrial countries, the vast majority of developing countries have neither adopted fully flexible exchange rates nor joined monetary unions.

Industrial countries are typically modeled either as operating flexible exchange rates or as members of a currency union, whereas in developing countries, officially determined rates, adjusted by a variety of alternative rules (loosely referred to as "managed" rates) predominate. A brief description of the nature of exchange-rate regimes in individual developing countries is presented in Chapter 8. 
(c) Copyright, Princeton University Press. No part of this book may be distributed, posted, or reproduced in any form by digital or mechanical means without prior written permission of the publisher.

Exchange-rate regimes in developing countries have evolved toward greater flexibility since the collapse of the Bretton Woods system in 1973. However, in practice this has meant either more frequent adjustments of an officially determined parity or the adoption of market-determined exchange rates with extensive official intervention. The prevalence of intermediate exchange-rate regimes implies that issues relating to the macroeconomic consequences of pegging, of altering the peg (typically in the form of a devaluation), and of rules for moving the peg are of particular importance in developing countries. These issues are discussed in Chapters 8 and 9.

\section{3 - Domestic Financial Markets}

6. Financial systems in many developing nations have been the subject of extensive deregulation in recent years. However, they continue to be dominated by banks. They also remain fragile and often exacerbate macroeconomic and financial volatility.

Although several developing countries have recently developed very large equity markets, such markets (as well as secondary markets for securities) continue to be small or nonexistent in many of them. Financial markets in the vast majority of developing economies continue to be dominated by a single type of institutionthe commercial bank. Thus, the menu of assets available to private savers is limited. Moreover, even where equity markets have developed, they tend to be dominated by a few closely held firms and exhibit very low turnover ratios.

The commercial banking sector in developing countries has traditionally been heavily regulated: it has often been subjected to high reserve and liquidity ratios as well as legal ceilings on interest rates together with sectoral credit allocation quotas. Over the last two decades, however, many countries have taken steps to deregulate their financial markets, resulting in enhanced competition, greater access to foreign banks, and improved efficiency. Rather than being legally imposed, as before, credit rationing in the developing world tends now to be endogenously generated by information asymmetries, as is commonly taken to be the case in industrial countries.

Nevertheless, the financial system remains, in many countries, underdeveloped. In spite of the more limited range of financial assets available to savers in developing nations, monetization ratios (as measured by the ratio of a monetary aggregate to nominal GDP) are generally lower for such countries than for industrial countries. In large part because of the nature of the financial system, but also because of some of the other features mentioned previously, the specification of standard textbook macroeconomic behavioral relationships (decision rules) may need to be modified in the developing-country context. In particular, it becomes necessary to incorporate the implications of credit rationing in private decision rules when such rationing is present. This affects, for instance, private consumption, investment, and asset demand functions. The incorporation of these phenomena has been treated in 
(c) Copyright, Princeton University Press. No part of this book may be distributed, posted, or reproduced in any form by digital or mechanical means without prior written permission of the publisher.

different ways - by including, for instance, quantity constraints in consumption and investment equations. These issues are taken up in Chapter 2.

Another issue relates to the fact that the institutional prerequisites for successful liberalization - in the form of appropriate regulatory and supervisory mechanismshave frequently not been in place, resulting in enhanced macroeconomic instability and severe crises involving interactions between the balance of payments and the financial system. As discussed in Chapters 14 and 15, the weakness of the institutional framework in many developing countries has made both the frequency and depth of such crises much more extensive in such countries than in industrial countries.

\subsection{The Government Budget}

7. The composition of the government budget differs markedly between industrial and developing countries.

In many developing nations, the state plays a pervasive role in the economy. This role is exercised through the activities of not just the nonfinancial public sector (consisting of the central government, local governments, specialized agencies, and nonfinancial public enterprises), but also of financial institutions owned by the government. Regarding the nonfinancial public sector itself, the government tends to play a more active role in production than is the case in most industrial nations, and the performance of public-sector enterprises is often central in determining the fiscal stance.

Unfortunately, systematic data on the size and performance of the consolidated nonfinancial public sector are not available for a large number of developing countries. Published information tends to refer to the finances of the central government only. Even so, existing studies suggest that the central government absorbs a smaller fraction of output in developing than in industrial countries, and that the composition of spending differs between the two groups of countries. Developing nations devote a substantially larger fraction of expenditures to general public services, defense, education, and other economic services (reflecting the role of government in production) than do industrial nations, whereas the latter spend somewhat more on health and substantially more on social security.

As for revenue, the main source of central government revenue is taxation, but the share of nontax revenue in total revenue tends to be much higher in developing than in industrial countries. The collection of tax revenue in developing countries is often hindered by limited administrative capacity and political constraints (Bird and Zolt, 2005). One consequence of this is that direct taxation plays a much more limited role in developing than in industrial nations; as noted by Bird and Zolt (2005), the tax structure in most developing countries is dominated by taxes on consumption, whereas in industrial countries, income taxes account for the largest share and taxes on foreign trade are negligible. Of direct taxes, the share of tax revenue 
(c) Copyright, Princeton University Press. No part of this book may be distributed, posted, or reproduced in any form by digital or mechanical means without prior written permission of the publisher.

raised from individual incomes (which often amount to withholding taxes on labor income in the formal sector) tends to be much larger than that from corporations in the developing world, whereas the reverse is true in the industrial world. In part, this is the result of high collection costs on capital income. Trade taxes consist primarily of import rather than export duties in developing countries and are used more extensively in the poorest countries.

The political and administrative constraints on tax collection in developing nations, coupled with the limited scope for the issuance of domestic debt in many such countries, has led to greater reliance on seigniorage, and therefore to higher levels of inflation (on average), than in industrial countries. With few exceptions, industrial countries tend to raise fairly low amounts (less than 1 percent of GDP) of seigniorage revenue, whereas many developing countries have traditionally collected significant amounts in this fashion. As a result, inflation rates in developing countries tend to be higher than those that prevail in the industrial world.

The macroeconomic implications of budget institutions - the set of rules and procedures by which government budgets are prepared, revised, and approved by the legislature-has attracted renewed interest, particularly in Latin America (see Grisanti et al., 1998, and Agénor and Yilmaz, 2011). Four dimensions, in particular, have been much discussed: (a) the nature (and credibility effects) of the constitutional rules that can be implemented to impose constraints on the size of the fiscal deficit, such as balanced-budget rules; $(b)$ the procedural rules (whether "collegial" or "hierarchical" ) that guide the elaboration of the budget by the executive branch, its approval by the legislative branch, and its execution; $(c)$ the transparency of the budgetary process; and (d) the implications of alternative fiscal rules for growth. It has been argued, for instance, that in a volatile environment asymmetric balancedbudget rules (which prevent borrowing in "bad" times but impose no saving in "good" ones) may be overly restrictive-possibly forcing a procyclical reaction to adverse economic shocks. By contrast, imposing an upper limit on the debt-tooutput ratio may be desirable, especially as a means to ensure fiscal sustainability (see Chapter 3). It has also been suggested that, in Latin America, better budgetary institutions are associated with lower fiscal deficits and stocks of public debt, but that at the same time high inflation and the volatility of economic activity have tended to reduce the ability of the budgetary process to impose fiscal discipline (Aizenman and Hausmann, 1995).

\subsection{Aggregate Supply and the Labor Market}

8. The large direct role that the state has played in production in many developing countries implies that the size and efficiency of the public capital stock figures prominently in the aggregate (or sectoral, under the three-good classification suggested earlier) production function(s). 
(c) Copyright, Princeton University Press. No part of this book may be distributed, posted, or reproduced in any form by digital or mechanical means without prior written permission of the publisher.

Nonfinancial public enterprises have been important economic actors in most of the developing world. Public capital represents a much larger share of the aggregate capital stock in such countries than in developed nations. Although reliable capital stock data are not available for such countries, existing data do indeed show that in many countries the public sector accounts for a sizable share of total investment. Given the important role that the public sector has played in the development process, the medium-term supply-side effects of government spending often cannot be ignored.

In recent years, the traditional role of the public sector as producer in developing countries has received new scrutiny, and several developing countries have undertaken massive privatizations of nonfinancial public enterprises. Because of the relatively large weight of public sector production in developing countries relative to that in industrial countries, the macroeconomic implications of such measures have been particularly important in the developing-country context.

9. Imported intermediate goods play an important role in the aggregate (or, under the three-good structure, sectoral) production function(s) in developing countries.

Imported intermediate goods play a prominent role in economic activity in the developing world. Such goods account for a sizable fraction of all developingcountry imports. In some countries the share of energy and non-energy intermediate imports can even exceed 70 percent. As a result, the difference between the value of domestic production and domestic value added tends to be larger in developing than in industrial nations. Through the cost of imported intermediates, the exchange rate has an important influence on the position of the economy's short-run supply curve. The role of imported intermediate goods means not only that exchange-rate changes will have short-run supply effects, but also that, in the presence of foreign exchange rationing, the availability of foreign exchange may have a direct effect on the position of the economy's short-run supply curve. The role of intermediate goods in the formulation of open-economy macroeconomic models is discussed in Chapter 12.

10. Short-run supply functions in developing economies may be significantly affected by working-capital considerations.

Because of the underdeveloped nature of the financial system, firms in many developing countries tend to rely on bank credit to finance their working-capital needs (labor costs and imported intermediate goods) prior to the sale of output. The existence of these needs implies that shocks to official interest rates and credit availability may play an important supply-side role in the short run; they imply, for instance, that a contractionary monetary policy may have short-run stagflationary consequences. This issue is discussed further in Chapter 6. 
(c) Copyright, Princeton University Press. No part of this book may be distributed, posted, or reproduced in any form by digital or mechanical means without prior written permission of the publisher.

11. Although labor market institutions vary substantially across developing countries, the informal sector continues to play an important role in the determination of wages and employment in many of them.

The nature of short-run wage-setting behavior represents one of the key differences between the major schools of modern macroeconomics, but most participants in these disputes acknowledge that country-specific institutional differences (such as the prevalence of staggered overlapping contracts in the United States or synchronized wage bargaining in Scandinavia) are important in determining the economy's short-run supply behavior. In this context, the role of economy-wide backward indexation mechanisms in the context of disinflation programs has received much attention. Despite the importance of labor market institutions in wage formation, however, the (limited) empirical evidence available on wage-setting behavior in developing countries suggests that many of them are characterized by a high degree of real wage flexibility (Horton et al., 1994; Agénor, 2006b).

There is also increasing recognition of the macroeconomic role played by the informal urban sector, which can account for a sizable proportion (50-60 percent, and in some cases even more) of economic activity and total employment in developing countries, particularly in some parts of Asia, the Middle East, and SubSaharan Africa. A consequence of the formal-informal dualism is the segmentation of the urban labor market, which plays a crucial role in explanations of urban poverty, unemployment, and underemployment in developing countries.

\section{6 - Stability of Policy Regimes}

12. Policy regimes tend to change much more frequently in developing countries than in industrial countries.

High inflation has been a symptom of policy instability and has frequently been associated with policy uncertainty. In large parts of the developing worldparticularly in Latin America and Africa-policy instability has been endemic. In part, this has been the result of indigenous factors. Political instability has characterized many developing countries from the time of their independence, and multiparty democracies with free elections remain rare. Changes in government not infrequently signal changes in ruling ideologies and correspondingly in economic policy regimes.

Policy uncertainty has been an important factor in the macroeconomics of development, in many instances triggering currency substitution, capital flight, exchange-rate crises, and the collapse of private investment. Uncertainty regarding the policy environment-or the anticipation of future policy reversals-is a feature that frequently must be built into developing-country macroeconomic models and the design of macroeconomic reform programs. 
(C) Copyright, Princeton University Press. No part of this book may be distributed, posted, or reproduced in any form by digital or mechanical means without prior written permission of the publisher.

\section{7 - Macroeconomic Volatility and Fluctuations}

13. As a result of many of the phenomena described previously, the macroeconomic environment in developing countries is often much more volatile than that in industrial countries.

A critical feature of the macroeconomic environment in many developing countries is instability of macroeconomic outcomes. The roots of this macroeconomic instability are both external and internal. Volatility in the terms of trade and in international financial conditions is directly transmitted to small developing countries that are price takers in international markets for goods and services as well as for financial assets. Coupled with the inflexibility of domestic macroeconomic instruments and political instability resulting in frequent and discrete changes in policy regimes in weak institutional settings, the macroeconomic experience of many developing countries has tended to be punctuated by a series of crises. These have had implications for a broad range of macroeconomic phenomena. Components of the government's budget, for instance, tend to be much less stable in developing countries than is typically the case in industrial countries. Instability has also characterized macroeconomic relative prices such as the terms of trade and real exchange rate. Most important, macroeconomic instability has resulted in unstable growth rates of real output as well as of private consumption. There is also evidence that macroeconomic volatility in some countries (particularly in Latin America) may have been compounded by a procyclical fiscal policy response-a tendency for government expenditure and fiscal deficits to increase during periods of economic expansion and to fall during recessions (Gavin and Perotti, 1997). Overall, boom and bust phenomena tend to be much more common in developing than in industrial countries; the higher degree of macroeconomic volatility that results from such phenomena are correspondingly more costly in the former group of countries. Indeed, using small calibrated models of archetype economies with a single representative consumer, Pallage and Robe (2003) found that macroeconomic volatility may entail large welfare losses and that even if consumers are only moderately risk averse, eliminating these fluctuations altogether may be preferable, from a welfare perspective, to a permanent increase in consumption growth.

14. In part as a result of greater exposure to volatility, features of macroeconomic fluctuations in developing countries differ significantly from those characterizing industrial countries. In particular, supply-side and external shocks play a more prominent role.

A related issue is that the sources of macroeconomic fluctuations differ significantly between industrial and developing countries. Developing countries not only experience shocks that differ in type and amplitude from those experienced in industrial countries, but also the domestic macroeconomic environment in which 
(C) Copyright, Princeton University Press. No part of this book may be distributed, posted, or reproduced in any form by digital or mechanical means without prior written permission of the publisher.

these shocks play themselves out tends to be quite different in the developing-country setting from what is typically assumed in industrial-country macroeconomic analysis. Thus, both the sources of macroeconomic shocks and their propagation mechanisms are likely to differ in the developing world.

Agénor et al. (2000) provide a systematic attempt to document a wide range of regularities in macroeconomic fluctuations for a group of twelve developing countries with diverse experiences with structural change and for which quarterly data of reasonable quality could be assembled (Colombia, Chile, India, Korea, Malaysia, Mexico, Morocco, Nigeria, the Philippines, Tunisia, Turkey, and Uruguay). The data they use cover a wide range of macroeconomic variables and include industrial output, prices, wages, various monetary aggregates, domestic private sector credit, fiscal variables, exchange rates, and trade variables. The relationship between economic fluctuations in these countries and two key indicators that proxy for economic activity in industrial countries - an index of industrial-country output and a measure of the world real interest rate-are also examined.

To examine economic fluctuations at business cycle frequencies, it is necessary to decompose all macroeconomic series into nonstationary (trend) and stationary (cyclical) components, because certain empirical characterizations of the data, including cross-correlations, are valid only if the data are stationary. Agénor et al. (2000) use three alternative filters, to examine the robustness of their results: a modified version of the Hodrick-Prescott filter (see Hodrick and Prescott, 1997); the band-pass filter, developed by Baxter and King (1999) and extended by Christiano and Fitzgerald (2003); and a nonparametric detrending method.

In line with much of the literature, Agénor et al. (2000) measure the degree of comovement of a series $y_{t}$ with industrial output $x_{t}$ by the magnitude of the correlation coefficient $\rho(j), j \in\{0, \pm 1, \pm 2, \ldots\}$. These correlations are between the stationary components of $y_{t}$ and $x_{t}$, with both components derived using the same filter. A series $y_{t}$ is said to be procyclical, acyclical, or countercyclical, depending on whether the contemporaneous correlation coefficient $\rho(0)$ is positive, zero, or negative. In addition, the series $y_{t}$ is said to be strongly contemporaneously correlated if $0.26 \leq|\rho(0)|<1$, weakly contemporaneously correlated if $0.13 \leq|\rho(0)|<0.26$, and contemporaneously uncorrelated with the cycle if $0 \leq|\rho(0)|<0.13{ }^{3}$

The cross-correlation coefficients $\rho(j), j \in\{0, \pm 1, \pm 2, \ldots\}$ indicate the phaseshift of $y_{t}$ relative to the cycle in industrial output. Again, in line with the existing literature, $y_{t}$ is said to lead the cycle by $j \operatorname{period}(s)$ if $|\rho(j)|$ is maximum for a positive $j$, to be synchronous if $|\rho(j)|$ is maximum for $j=0$, and to lag the cycle if $|\rho(j)|$ is maximum for a negative $j .{ }^{4}$ To establish which correlations are significantly different from zero, they use the following result, established by Kendall

\footnotetext{
${ }^{3}$ The approximate standard error of these correlation coefficients, computed under the null hypothesis that the true correlation coefficient is zero, and given the average number of observations per country in the sample, is about 0.13 .

${ }^{4}$ The pattern of lead-lag correlations and, in particular, the lag at which the peak positive correlation occurs, could be interpreted as indicating the speed with which innovations in variable $y_{t}$ are transmitted to real activity $x_{t}$.
} 
(C) Copyright, Princeton University Press. No part of this book may be distributed, posted, or reproduced in any form by digital or mechanical means without prior written permission of the publisher.

and Stuart (1967, pp. 292-93): the statistic $\ln [(1+\rho) /(1-\rho)] / 2$, where $\rho$ is the bivariate correlation coefficient between detrended output and detrended $x_{t}$, has an asymptotically normal distribution with a variance equal to $1 /(T-3)$, where $T$ is the number of observations. With 27 observations, for instance, this implies that positive correlations of 0.32 or larger are significantly different from zero at the 10 percent level, and of 0.48 or greater are significant at the 1 percent level.

Their main findings can be summarized as follows:

- Output volatility, as measured by standard deviations of the filtered cyclical component of industrial production, varies substantially across developing countries, but is on average much higher than the levels typically observed in industrial countries. This is consistent with the results in Neumeyer and Perri (2005) and Calderón and Fuentes (2014). ${ }^{5}$ There is also considerable persistence (as measured by autocorrelation coefficients) in output fluctuations in developing countries.

- Activity in industrial countries has a positive but relatively weak influence on output in developing countries, in contrast to the results of Hoffman (2007). Real interest rates in industrial countries tend to be positively associated with output fluctuations in developing countries; these results are consistent with those of Ahmed (2003), Neumeyer and Perri (2005), and Uribe and Yue (2006), regarding the impact of U.S. interest rates.

- Government expenditure is countercyclical. Government revenues are acyclical in some countries, and significantly countercyclical in others, a phenomenon that appears difficult to explain. The ratio of government spending to government revenue is negatively correlated with the business cycle.

- The cyclical behavior of nominal wages varies markedly across countries and is not robust across filters. By contrast, the evidence strongly supports the assumption of procyclical real wages.

- There is no consistent relationship between the stationary components of the levels of output and prices, or the levels of output and inflation. Variations in the price level and inflation are countercyclical in a number of countries and procyclical in a few.

- Contemporaneous correlations between money (measured through various monetary aggregates) and output are broadly positive, but not very strong-in contrast to the evidence for many industrial countries.

- The contemporaneous correlations between the velocity of broad money and industrial output are strongly negative across all filters for almost all the countries in our sample. This result is in contrast to the weakly procyclical behavior of velocity observed in most advanced industrial countries.

\footnotetext{
${ }^{5}$ Pallage et al. (2006) estimate that the percentage volatility of per capita consumption in developing countries (excluding countries affected by civil wars) has typically been two to six times greater than in industrialized countries over the past three decades.
} 
(C) Copyright, Princeton University Press. No part of this book may be distributed, posted, or reproduced in any form by digital or mechanical means without prior written permission of the publisher.

- Domestic credit and industrial output are positively associated for some countries. However, the strength of the relationship between credit and output is not always robust to the choice of detrending procedure. In some countries, there is a negative correlation between these two variables.

- There is no robust correlation between merchandise trade movements (as measured by the ratio of exports to imports) and output. For some countries, the contemporaneous correlations are negative (irrespective of the filter used), whereas for others the contemporaneous correlations are strongly positive-the latter result possibly indicating that industrial output fluctuations are driven by export demand and that merchandise imports are not as sensitive to domestic demand fluctuations as in industrial countries.

- Cyclical movements in the terms of trade are strongly and positively correlated with output fluctuations.

- There are no systematic patterns in the contemporaneous correlations between nominal effective exchange rates and industrial output; in addition, for a majority of the countries under study, these correlations are not significantly different from zero. Similar results are obtained for real effective exchange rates.

These results highlight the importance of external and supply-side shocks in driving business cycles in developing countries. They are in line with those for a number of industrial countries and those obtained by Hoffmaister and Roldós (1997, 2001), Hoffmaister et al. (1998), Kalulumia and Nyankiye (2000), Kose and Riezman (2001), Kose (2002), and Frankel et al. (2013). ${ }^{6}$ Subsequent research by Claessens et al. (2011) and Calderón and Fuentes (2014) confirmed a strong correlation between financial cycles (as measured by credit growth and changes in asset prices) and the business cycle. ${ }^{7}$ Of course, using cross-correlation coefficients as indicators for evaluating the empirical relevance of demand-oriented, versus supplyoriented, macroeconomic theories can be problematic. ${ }^{8}$ The results are also not uniform across countries. In particular, whereas negative price-output correlations in some countries provide support for "real" or supply-side interpretations of business cycles, countries where price-output correlations are positive would tend to support demand-side interpretations.

\footnotetext{
${ }^{6}$ Raddatz (2007) appears to be the only study that departs from the consensus on the quantitative importance of external shocks in explaining output volatility; however, he focuses only on low-income countries.

${ }^{7}$ Claessens et al. (2011) found that recessions are longer and deeper when accompanied by financial disruptions-the average output decline in a recession rises from 5 percent if there is no concomitant credit crunch to 8.5 percent if there is one. Likewise, recessions associated with equity price busts result in a 6.8 percent decline in output, on average, versus a milder 3.3 percent fall in the absence of such busts. Both studies document the procyclicality of bank financial intermediation.

${ }^{8}$ More generally, covariation among a set of variables may depend not only on the nature of the shocks that perturb the economy, but also (under rational expectations) on how long the lag is between perception (announcement) and realization (implementation) of the shock.
} 
(c) Copyright, Princeton University Press. No part of this book may be distributed, posted, or reproduced in any form by digital or mechanical means without prior written permission of the publisher.

\section{8 - Income Inequality}

15. The degree of income inequality tends to be much higher in developing than industrial countries. Income inequality has important implications not only for growth and development, but also for short-run macroeconomic fluctuations.

The high degree of inequality that characterizes the distribution of income in developing countries is well documented (see, for instance, Todaro and Smith, 2011), and much research on the economic effects of income inequality focuses on its implications for growth and long-term development. However, a highly unequal distribution of income may also have short-run macroeconomic implications. Countries characterized by high levels of income inequality tend to have a small and volatile tax base; this may translate into high volatility of (public) expenditure and output (Woo, 2005). Indeed, Woo (2011) found evidence that more unequal societies are more likely to resort to more procyclical fiscal policies.

Alternatively, as argued by Iyigun and Owen (2004), the degree of income inequality can affect private consumption variability when the ability to obtain credit depends on income. Essentially, when income plays a role in access to credit, the distribution of income contains information about the fraction of individuals who are credit-constrained and cannot smooth consumption. If credit is so abundant that only the lower class is shut out of credit markets and unable to smooth consumption through downturns, greater inequality (a smaller middle class) is likely to be associated with more volatility in consumption. In contrast, if the availability of credit is limited to such an extent that both the lower and middle classes are credit-constrained, a more unequal distribution of income is likely to result in smoother aggregate consumption. Put differently, when credit-constrained and -unconstrained individuals have different consumption smoothing abilities, the distribution of wealth and income can affect aggregate fluctuations because it determines the fraction of individuals who are credit-constrained.

Using cross-country panel data for the period 1969-1992, Iyigun and Owen found that greater income inequality is associated with less consumption variability when per capita income is low. By contrast, when per capita income is high, greater income inequality is associated with higher consumption variability. Thus, the distribution of income affects the short-run variability of consumption differently in high- and low-income countries-possibly because financial development and availability of credit are positively associated with higher levels of per capita income, as discussed in Chapter 18.

\section{A General Accounting Framework}

All macroeconomic models are based on an accounting framework that, in essence, describes the intratemporal budget constraints confronting all types of economic 
(c) Copyright, Princeton University Press. No part of this book may be distributed, posted, or reproduced in any form by digital or mechanical means without prior written permission of the publisher.

agents included in the model. The accounting framework does little more than specify the set of choices that can be made by each type of agent. The model is completed by adding decision rules governing such choices and equilibrium conditions reconciling the decisions made by different agents. In this section we describe a general accounting framework on which a large variety of particular developingcountry macroeconomic models can be based. Our purpose is to adapt the standard industrial-country macroeconomic accounting framework to the developing-country characteristics described earlier.

The first step is to specify the list of agents involved. We shall discuss in turn the nonfinancial private sector, the nonfinancial public sector, the central bank, and the commercial banking system.

\section{1 - The Nonfinancial Private Sector}

In describing the budget and balance sheet constraints faced by the nonfinancial private sector, a logical place to begin is the specification of the menu of assets available to private agents. This is, of course, a function of the degree of sophistication of the country's financial system. In several middle-income developing nations, small equity markets have been in existence for some time, and in some countries government bonds are sold to the nonbank private sector and are traded in secondary markets. In the rest of the developing world, however, these phenomena are exceptional. Moreover, the analysis of macroeconomic models with these features is familiar from standard industrial-country applications (see Buiter, 1980). Thus, the portfolio choices that will be described here are those that are relevant for developing countries with less-developed financial systems.

The nonfinancial private sector holds both financial and real assets. Financial assets consist of currency issued by the central bank $C U$, deposits issued by the commercial banks $D^{p},{ }^{9}$ net foreign assets $E F^{p}$ (where $E$ is the exchange rate expressed as the domestic-currency price of foreign currency and $F^{p}$ is the foreigncurrency value of these assets), and loans extended by households in informal markets, $L^{b}$. Liabilities of the sector consist of credit from banks, $L^{p}$, and loans received through informal markets. The sector's real assets consist of inflation hedges (typically real estate or gold), with price $p_{H}$ and quantity $\bar{H}^{10}$ In the absence of equity markets, physical capital is treated in the same manner as human capital - that is, as a nonmarketable asset that generates income available to finance consumption-but does not represent a component of households' marketable portfolios. Under these conditions, the nonfinancial private sector's marketable net

\footnotetext{
${ }^{9}$ Of course, in many macro models it is desirable to disaggregate deposits into demand and time deposits, because demand functions for these assets differ in general. For the purpose at hand, though, this distinction is unimportant, because both types of deposits are assets of the private nonfinancial sector and liabilities of the banking system.

${ }^{10} \mathrm{We}$ shall assume that there is a fixed stock of these, given by $\bar{H}$, so that whereas the price of such hedges can vary over time, their quantity cannot.
} 
(C) Copyright, Princeton University Press. No part of this book may be distributed, posted, or reproduced in any form by digital or mechanical means without prior written permission of the publisher.

worth $\Omega^{p}$ is:

$$
\Omega^{p}=C U+D^{p}+E F^{p}+p_{H} \bar{H}-L^{p} .
$$

Note that loans extended through the informal market do not affect net worth, because these loans are transacted entirely within the nonfinancial private sector and thus do not represent a claim by the sector on the rest of the economy.

Differentiating (1) with respect to time yields

$$
\dot{\Omega}^{p}=C \dot{U}+\dot{D}^{p}+\dot{E} F^{p}+E \dot{F}^{p}+\dot{p}_{H} \bar{H}-\dot{L}^{p} .
$$

The change in the marketable net worth of the nonfinancial private sector consists of the purchase of financial assets (financial saving, denoted $S^{p}$ ) plus capital gains:

$$
\dot{\Omega}^{p}=S^{p}+\dot{E} F^{p}+\dot{p}_{H} \bar{H}
$$

From (2) and (3), $S^{p}$ is given by ${ }^{11}$

$$
S^{p}=C \dot{U}+\dot{D}^{p}+E \dot{F}^{p}-\dot{L}^{p} .
$$

Finally, financial saving is the difference between disposable income and expenditure on consumption and investment:

$$
S^{p}=Y+i_{d} D^{p}+i^{*} E F^{p}-i_{c} L^{p}-\tau^{p}-C^{p}-I^{p} .
$$

Equation (5) indicates that disposable income consists of factor income $Y$ plus net interest income (income from deposits and foreign assets minus interest payments on bank credit, where the respective interest rates are given by $i_{d}, i^{*}$, and $i_{c}$ ), minus net taxes $\tau^{p}$. Private consumption is $C^{p}$, and private investment is $I^{p}$.

\section{2 - The Public Sector}

\subsubsection{The Nonfinancial Public Sector}

The nonfinancial public sector is typically a substantial net financial debtor. Its debt is owed to the central bank $\left(L^{b g}\right),{ }^{12}$ to commercial banks $\left(L^{c g}\right)$, and to foreigners

\footnotetext{
${ }^{11}$ Note that financial saving does not include the acquisition of inflation hedges. This is because their stock is fixed and they are held only by the nonfinancial private sector, so they cannot be acquired from agents outside the sector.

${ }^{12} L^{b g}$ denotes net credit to the public sector from the central bank. As such, it is the sum of public sector bonds held by the central bank plus bank credit in the form of, say, overdrafts, minus public sector deposits.
} 
$\left(-E F^{g}\right) \cdot{ }^{13}$ The nonfinancial public sector's net worth, $\Omega^{g}$, is thus given by

$$
\Omega^{g}=E F^{g}-L^{b g}-L^{c g} .
$$

The change in $\Omega^{g}$ over time obeys

$$
\dot{\Omega}^{g}=\dot{E} F^{g}+E \dot{F}^{g}-\dot{L}^{b g}-\dot{L}^{c g},
$$

which consists of new borrowing by the nonfinancial public sector, $-S^{g}$, plus capital gains on net foreign assets:

$$
\dot{\Omega}^{g}=S^{g}+\dot{E} F^{g}
$$

From equations (7) and (8), $S^{g}$ consists of

$$
S^{g}=E \dot{F}^{g}-\dot{L}^{b g}-\dot{L}^{c g} .
$$

Total new borrowing by the nonfinancial public sector must be equal to the overall fiscal deficit:

$$
-S^{g}=C^{g}+I^{g}+i_{b} L^{b g}+i_{c} L^{c g}-i^{*} E F^{g}-\tau^{p}-\tau^{g},
$$

where $\tau^{g}$ represents transfers from the central bank to the nonfinancial public sector and $i_{b}$ the interest rate paid on loans received from the central bank.

\subsubsection{The Central Bank}

The central bank's balance sheet will prove to play a central role in many of the models examined in this book. Under present assumptions, it is given by

$$
\Omega^{b}=E R^{*}+\left(L^{b g}+L^{b c}\right)-M,
$$

where $R^{*}$ represents net foreign assets of the central bank, $L^{b c}$ credit from the central bank to commercial banks, and $M$ high-powered money (or the monetary base), defined as the sum of currency held by the nonfinancial private sector and reserves of the commercial banking system held in the vaults of the central bank, $R R$ :

$$
M=C U+R R
$$

\footnotetext{
${ }^{13}$ The minus sign is introduced here because we shall adopt, for uniformity, the convention that the symbol $F$ denotes a net claim on the rest of the world.
} 
(c) Copyright, Princeton University Press. No part of this book may be distributed, posted, or reproduced in any form by digital or mechanical means without prior written permission of the publisher.

As with the other sectors, the change in $\Omega^{b}$ can be written as

$$
\dot{\Omega}^{b}=E \dot{R}^{*}+\dot{E} R^{*}+\left(\dot{L}^{b g}+\dot{L}^{b c}\right)-\dot{M},
$$

or

$$
\dot{\Omega}^{b}=S^{b}+\dot{E} R^{*}
$$

where $S^{b}$ is given by

$$
S^{b}=E \dot{R}^{*}+\left(\dot{L}^{b g}+\dot{L}^{b c}\right)-\dot{M} .
$$

$S^{b}$ is referred to as the "quasi-fiscal" surplus (or, when negative, deficit). ${ }^{14}$ It is the difference between the central bank's earnings and its expenditures. The former consist of interest earnings on net foreign exchange reserves, credit to commercial banks, and net credit to the nonfinancial public sector; the latter consist of transfers to the government $\tau^{g}$ :

$$
S^{b}=i^{*} E R^{*}+i_{b}\left(L^{b g}+L^{b c}\right)-\tau^{g},
$$

where, for simplicity, we assume that the central bank charges the same interest rate $i_{b}$ on its loans to the government and to commercial banks.

Equation (15) can be rewritten in a useful way to derive the sources of base money growth:

$$
\dot{M}=\dot{L}^{b g}+E \dot{R}^{*}-S^{b}+\dot{L}^{b c}
$$

Equation (17) indicates that the sources of base money growth consist of central bank financing of the nonfinancial public sector, balance-of-payments surpluses, quasi-fiscal deficits, and credit extended by the central bank to the private banking system.

\subsubsection{The Consolidated Public Sector}

The consolidated public sector consists of the nonfinancial public sector and the central bank. Using (6) and (11), the financial net worth of the consolidated public sector, $\Omega^{p s}$, is given by

$$
\Omega^{p s}=\Omega^{g}+\Omega^{b}=E\left(F^{g}+R^{*}\right)+\left(L^{b c}-L^{c g}\right)-M,
$$

\footnotetext{
${ }^{14} \mathrm{~A}$ discussion of quasi-fiscal deficits is provided in Chapter 3.
} 
which changes over time according to

$$
\dot{\Omega}^{p s}=E\left(\dot{F}^{g}+\dot{R}^{*}\right)+\left(\dot{L}^{b c}-\dot{L}^{c g}\right)-\dot{M}+\dot{E}\left(F^{g}+R^{*}\right) .
$$

From (9) and (15), its financial saving consists of

$$
S^{p s}=S^{g}+S^{b}=E\left(\dot{F}^{g}+\dot{R}^{*}\right)+\left(\dot{L}^{b c}-\dot{L}^{c g}\right)-\dot{M},
$$

so that (19) can alternatively be written as

$$
\dot{\Omega}^{p s}=S^{p s}+\dot{E}\left(F^{g}+R^{*}\right) .
$$

The overall financial surplus of the consolidated public sector is given by, from (10) and (16):

$$
S^{p s}=S^{g}+S^{b}=\left(\tau^{p}-C^{g}-I^{g}\right)+i_{b} L^{b c}+i^{*} E\left(F^{g}+R^{*}\right)-i_{c} L^{c g} .
$$

Other useful concepts of the overall public sector accounts are the primary surplus (consisting of the non-interest portion of the overall public sector surplus) and the operational surplus, which excludes the inflation component of nominal interest transactions and thus consists of the primary surplus plus real interest payments. These concepts will be examined in more detail in Chapter 3.

\section{3 - The Commercial Banking System}

The commercial banks' financial net worth $\Omega^{c}$ is the difference between bank assets and liabilities that have already been identified:

$$
\Omega^{c}=L^{p}+L^{c g}+R R-D^{p}-L^{b c},
$$

which changes over time according to

$$
\dot{\Omega}^{c}=\dot{L}^{p}+\dot{L}^{c g}+R \dot{R}-\dot{D}^{p}-\dot{L}^{b c} .
$$

Because commercial banks are assumed to hold neither foreign assets nor inflation hedges, the change in banks' net worth over time simply consists of

$$
\dot{\Omega}^{c}=S^{c}=\dot{L}^{p}+\dot{L}^{c g}+R \dot{R}-\dot{D}^{p}-\dot{L}^{b c},
$$

and $S^{c}$ is given by

$$
S^{c}=i_{c}\left(L^{p}+L^{c g}\right)-i_{d} D^{p}-i_{b} L^{b c}
$$


(C) Copyright, Princeton University Press. No part of this book may be distributed, posted, or reproduced in any form by digital or mechanical means without prior written permission of the publisher.

\subsection{Aggregate Relationships}

Summing (1), (18), and (23), the economy's aggregate net worth $\Omega$ consists of its net international indebtedness (net claims on foreigners, $F$ ) plus its stock of inflation hedges:

$$
\Omega=\Omega^{p}+\Omega^{p s}+\Omega^{c}=E\left(F^{p}+F^{g}+R^{*}\right)+p_{H} \bar{H}=E F+p_{H} \bar{H},
$$

which grows over time according to

$$
\dot{\Omega}=E \dot{F}+\dot{E} F+\dot{p}_{H} \bar{H}
$$

Equation (28) can be derived by either differentiating (27) or summing (2), (19), and (24). From (8), (21), and (25), it can also be written as

$$
\dot{\Omega}=S^{p}+S^{p s}+S^{c}+\dot{E} F+\dot{p}_{H} \bar{H}=S+\dot{E} F+\dot{p}_{H} \bar{H},
$$

where $S$ represents national financial saving. Equations (28) and (29) imply

$$
S=E \dot{F},
$$

which indicates that national financial saving represents the net accumulation of claims on the rest of the world.

By summing (5), (22), and (26), $S$ can also be expressed as

$$
S=Y+i^{*} E F-\left(C^{p}+C^{g}\right)-\left(I^{p}+I^{g}\right),
$$

which indicates that national financial saving is the difference between gross national product, $G N P=Y+i^{*} E F$, and domestic absorption, $D A=\left(C^{p}+C^{g}\right)+\left(I^{p}+\right.$ $\left.I^{g}\right)$, which is the current account of the balance of payments, $C A$. The negative of national financial saving as used here is what is commonly referred to as foreign saving (the current account deficit). Some familiar macroeconomic identities can be derived from (31). First, defining total absorption by the nonfinancial public sector as $G=C^{g}+I^{g}$, and replacing $S$ by $C A$ yields the national income accounting identity:

$$
G N P=C^{p}+I^{g}+G+C A .
$$

Second, defining total national saving $S_{T}$ (the sum of aggregate financial and real saving) as the difference between national income and total consumption $\left(S_{T}=\right.$ $G N P-C^{p}-C^{g}$ ) yields the flow-of-funds version of (32):

$$
C A=S_{T}-\left(I^{p}+I^{g}\right),
$$


(C) Copyright, Princeton University Press. No part of this book may be distributed, posted, or reproduced in any form by digital or mechanical means without prior written permission of the publisher.

which is the standard identity linking total saving $\left(S_{T}-C A\right)$ to total investment $\left(I^{p}+I^{g}\right)$. Third, replacing $S$ by its value in $(30)$, we have, after sectoral disaggregation:

$$
E \dot{R}=\left(G N P-C^{p}-I^{p}-G\right)-E\left(\dot{F}^{p}+\dot{F}^{g}\right) .
$$

Equation (34) is the familiar balance-of-payments identity, expressed in domestic-currency terms. The left-hand side corresponds to reserve accumulation by the central bank (the overall balance of payments). The first term on the right-hand side is the current account and the second is the capital account.

\section{Production Structure in an Open Economy}

To convert the set of identities described in the preceding section to a macroeconomic model, economic behavior and equilibrium conditions must be specified. First, however, the degree of sectoral disaggregation must be determined. As suggested in the introduction, most open-economy macroeconomic models adopt one of three basic options. ${ }^{15}$ In this section we describe each of these in turn.

\section{1 - The Mundell-Fleming Model}

The most common analytical framework adopted in modeling the production structure in open-economy models of industrial countries is the Mundell-Fleming framework. ${ }^{16}$ This framework assumes that the economy specializes in the production of a single (composite) good, which is an imperfect substitute for the single (composite) good produced by the rest of the world. The law of one price holds for each individual good, so the domestic-currency price of the foreign good is equal to the foreign-currency (international) price (which we denote $P^{*}$ ) multiplied by the domestic-currency price of the foreign currency, $E$. Similarly, the foreign-currency price of the domestically produced good is its domestic-currency price, $P$, divided by the domestic-currency price of the foreign currency. Domestic residents demand both the domestic and foreign goods, as do foreign residents. Thus, the foreign good is the home economy's importable good, and the domestic good is its exportable good. The relative price of the foreign good in terms of the domestic good is referred to as

\footnotetext{
${ }^{15} \mathrm{~A}$ fourth option is the approach proposed by McCallum and Nelson (2000), in which imports are not treated as finished consumer goods but rather as intermediate goods, which are used (together with domestic intermediate goods) in the production of the domestic final good. As discussed in Chapter 12, this approach is particularly relevant for developing countries, where trade in raw materials accounts for a very large share of imports.

${ }^{16}$ See Mundell (1963) and Fleming (1962). The Mundell-Fleming model is presented in all standard texts on open-economy macroeconomics. For a particularly thorough description, see Frenkel and Razin (1987).
} 
(C) Copyright, Princeton University Press. No part of this book may be distributed, posted, or reproduced in any form by digital or mechanical means without prior written permission of the publisher.

the domestic economy's terms of trade or its real exchange rate. The two terms are interchangeable in the Mundell-Fleming model.

The key property of the Mundell-Fleming model is that the domestic economy's terms of trade are endogenous, because the home country is small in the market for its importable good but large-in the sense of possessing some degree of monopoly power-in the market for its exportable good. The latter implies that changes in domestic demand for the exportable good will affect its relative price or level of production. The mechanism through which it does so, and the extent to which equilibrium is restored through relative price or output adjustments, depends on the exchange-rate system and the short-run supply function for the exportable good. To illustrate the determination of the terms of trade, we examine a simple short-run Mundell-Fleming model that focuses only on the production side of the economy, that is, the goods and labor markets. We consider only the case of fixed exchange rates. ${ }^{17}$

Let $y$ represent output of the domestic good, $a$ the level of domestic absorption, and $b$ the trade balance, all measured in units of the domestic good. Also, let $z=$ $E P^{*} / P$ denote the terms of trade. Because domestic and foreign goods are imperfect substitutes, the trade balance can be written as

$$
b=b(\stackrel{+}{z}, \bar{a}), \quad-1<b_{a}<0,
$$

where the sign of the derivative with respect to the terms of trade assumes that the Marshall-Lerner condition holds. ${ }^{18}$ The equilibrium condition of the market for domestic goods is given by

$$
y=a+b(z, a) .
$$

The nature of the equilibrating mechanism depends on the supply side of the economy. In the short run, domestic output is determined by a production function that exhibits diminishing returns to labor:

$$
y=y(n), \quad y^{\prime}>0, y^{\prime \prime}<0
$$

where $n$ is the level of employment. Let $w$ denote the nominal wage, and $\omega$ the real wage in terms of the importable good. Then the real wage in terms of exportables is $w / P=\left(w / E P^{*}\right)\left(E P^{*} / P\right)=z \omega$, and labor demand $n^{d}$ is given by

\footnotetext{
${ }^{17}$ See Dornbusch (1980) for a description of the Mundell-Fleming model under flexible exchange rates.

${ }^{18}$ That is, if $x=x(z, \cdot)$ and $m=m(z, a, \cdot)$ represent the behavior of real exports and real imports, respectively, so that $b=x-z m$, assuming $b_{z}>0$ requires, at an initial value of $b=0$, that $\eta_{x z}+\eta_{m z}-1>0$, where $\eta_{x z}$ and $\eta_{m z}$ are demand elasticities for exports and imports, respectively.
} 
the profit-maximizing condition

$$
y^{\prime}(n)=z \omega \Rightarrow n^{d}=n^{d}(z \omega)
$$

where $n^{d^{\prime}}=1 / y^{\prime \prime}<0$. Finally, labor market equilibrium requires:

$$
n^{d}(z \omega)=\bar{n}
$$

where $\bar{n}$ is the exogenous supply of labor.

This model can be solved for $z$ as a function of $a$ under classical or Keynesian conditions. In the former case, the labor market clears, so (39) can be used to replace $n$ by $\bar{n}$ in (37), leaving (36) in the form

$$
y(\bar{n})=a+b(z, a)
$$

which determines $z$ implicitly as a function of $a$. The effect on $z$ of an increase in $a$ is given by $d z / d a=-\left(1+b_{a}\right) / b_{z}$, which has a negative sign: an increase in domestic absorption increases the domestic price level, so that the terms of trade improve. ${ }^{19}$ In the Keynesian mode, $\omega$ is exogenous and the labor market-clearing equation (39) does not hold. Substituting the demand for labor $n^{d}$ from (38) into (37) allows us to write $(40)$ in the form

$$
y\left[n^{d}(z \omega)\right]=a+b(z, a),
$$

which implies that, in this case, the relationship between $z$ and $a$ is $d z / d a=$ $\left(1+b_{a}\right) /\left(\omega y^{\prime} n^{d \prime}-b_{z}\right)<0$, because the numerator is positive and the denominator negative. A change in domestic absorption has a smaller effect on the terms of trade in the Keynesian case (the denominator of $d z / d a$ is larger in absolute value) because a change in $z$ elicits a supply as well as a demand response in this case, so a given change in $z$ is more effective in eliminating excess demand in the market for domestic goods.

The simultaneous determination of internal and external balance in this model is illustrated in Figure 1-1. The $C C$ schedule depicts the set of combinations of $z$ and a compatible with equilibrium in the market for home goods that prevails when the model operates in classical mode. The slope of $C C$ reflects the dependence of the terms of trade on domestic spending in the Mundell-Fleming model, as derived above. The $B B$ schedule depicts the set of combinations of $z$ and $a$ compatible with a given trade balance outcome, say a sustainable trade balance level $b_{0}$. It is derived from (35). Its slope is positive and given by $-b_{a} / b_{z}$. Points above $B B$ correspond to an improvement in the trade balance relative to $b_{0}$, and points below imply a deterioration relative to $b_{0}$. Equation (36) implies that the economy must always lie along $C C$, where the market for domestic goods clears. Given a level of absorption

\footnotetext{
${ }^{19}$ Given the solution for $z$, (39) determines the real wage in terms of importables, $\omega$.
} 
(C) Copyright, Princeton University Press. No part of this book may be distributed, posted, or reproduced in any form by digital or mechanical means without prior written permission of the publisher.

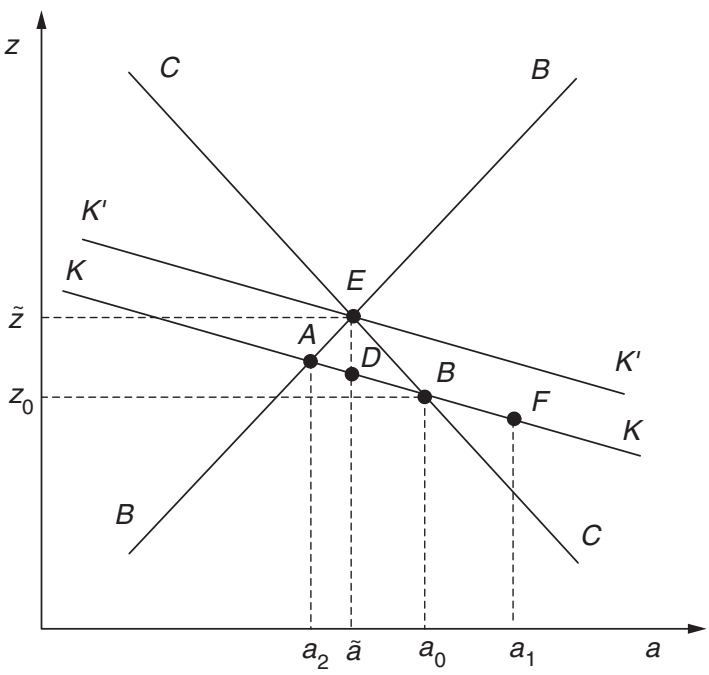

Figure 1-1 - Internal and External Balance in the Mundell-Fleming Model

$a_{0}, C C$ determines the value of $z$ required to clear the market for domestic goods, and the negative slope of $C C$ follows from the sign of $d z / d a$, derived above. In the figure, the equilibrium value of the terms of trade corresponding to $a_{0}$ is $z_{0}$. The trade balance at point $B$ corresponding to $\left(a_{0}, z_{0}\right)$ exhibits a deficit in excess of $b_{0}$. Thus, in the classical case, $B$ represents a point of internal, but not external, balance. The simultaneous achievement of external and internal balance, at point $E$, requires a reduction in domestic absorption from $a_{0}$ to $\tilde{a}$.

The commodity-market equilibrium schedule in the Keynesian mode is derived from (41). Its position depends on the initial value of the real wage measured in terms of importables, $\omega$. Graphically, a change in $\omega$ causes the commodity-market equilibrium locus to shift vertically. The shift is downward for an increase in $\omega$ and upward for a reduction in $\omega$. In both cases the magnitude of the shift is less than proportional to the change in $\omega .^{20}$ The Keynesian commodity-market equilibrium locus that passes through the initial point $B$ is labeled $K K$. Since $z$ is more responsive to $a$ in the classical than in the Keynesian mode, $K K$ is depicted in the diagram as flatter than $C C$. In the Keynesian case internal balance may not hold at $B$ since, although the goods market clears by assumption, the labor market equilibrium condition (39) may not hold..$^{21}$ Increasing absorption to $a_{1}$ would move the economy to $F$, achieving internal balance. However, this implies further departure from

\footnotetext{
${ }^{20}$ The magnitude of the shift is given by $d z / d \omega=-z /\left(\omega+b_{z}\right)$, so the proportional shift is $(d z / d \omega)(\omega / z)=$ $-\omega /\left(\omega+b_{z}\right)$.

${ }^{21}$ For a given value of $\omega$, there is a unique value of $z$ that satisfies (39), so this equation holds only at a single point along $K K$, say at $F$. Along $K K$ to the northwest of $F$, labor demand falls short of labor supply, and to the southeast of $F$, labor demand exceeds supply.
} 
(c) Copyright, Princeton University Press. No part of this book may be distributed, posted, or reproduced in any form by digital or mechanical means without prior written permission of the publisher.

external balance. An adjustment of absorption to $\tilde{a}$, as in the classical case, would fail to restore external balance (since the terms of trade would not deteriorate sufficiently) and move the economy further away from internal balance. Finally, external balance could be restored at point $A$, but this would move the economy further away from internal balance.

What is required in the Keynesian model is the simultaneous adjustment of absorption and the real wage in terms of importables. In the classical model, the latter is achieved through nominal wage flexibility. In the Keynesian model, it must be achieved by an adjustment in the nominal exchange rate. A reduction of absorption from $a_{0}$ to $\tilde{a}$, coupled with a nominal exchange-rate depreciation sufficient to shift $K K$ to $K^{\prime} K^{\prime}$, would simultaneously achieve external and internal equilibrium at point $E$.

\section{2 " The "Dependent Economy" Model}

The endogeneity of the terms of trade in the Mundell-Fleming model is inconsistent with the evidence cited earlier that developing countries tend to be small in the market for their exports, so that such countries in fact exert very little control over the world prices of their exports. If the terms of trade are instead taken as exogenous, but the Mundell-Fleming assumption of a single domestically produced good is retained, then domestic demand conditions would have no effect on either the price or output of the domestic good, since that good would effectively face an infinitely elastic world demand at a domestic-currency price determined by the law of one price. The only role for domestic demand in this case would be to determine the excess demand for the domestic good, and thus the trade balance.

This situation is unrealistic, because many domestic goods and services indeed cannot be sold abroad; transportation costs and commercial policies make such domestic goods uncompetitive in foreign markets. However, such goods and services may not be imported either, since trade barriers such as those mentioned may render their foreign equivalents uncompetitive in the domestic market. Goods and services of this type that can neither be sold nor bought abroad are referred to as nontraded. Nontraded goods are produced at home for sale at home.

The dependent economy model, according to Swan (1960) and Salter (1959), contains two domestic production sectors, one producing traded and the other nontraded goods. The traded goods sector consists of both importables and exportables. They can be aggregated into a single sector because the terms of trade are taken to be both exogenous, as suggested above, and constant, so that exportables and importables can be treated as a single Hicksian composite good. What matters for macroeconomic equilibrium is the total value of domestic production and consumption of traded goods, rather than either exportables or importables separately. Domestic residents are assumed to spend on both traded and nontraded goods. 
(c) Copyright, Princeton University Press. No part of this book may be distributed, posted, or reproduced in any form by digital or mechanical means without prior written permission of the publisher.

As already indicated, in the dependent economy model the terms of trade are constant. The law of one price holds for traded goods, so in the small-country case the domestic economy faces infinitely elastic world demand for exportables and supply of importables at their respective world market prices. The key relative price in the dependent economy model is the real exchange rate, defined as the price of traded goods in terms of nontraded goods, or $z=P_{T} / P_{N}$, where $P_{T}$ is the domestic-currency price of traded goods-measured in terms of exportables, importables, or any combination of these goods-and $P_{N}$ is the price of nontraded goods. Production in each sector is described by a linearly homogeneous sectoral production function in capital and labor, but in the short run each sector's capital stock is fixed. Labor, on the other hand, is homogeneous and intersectorally mobile. In the short run, supply of output in each sector depends on employment in that sector:

$$
y_{b}=y\left(n_{h}\right), \quad y_{b}^{\prime}>0, y_{b}^{\prime \prime}<0, \quad b=N, T,
$$

where $y_{T}$ and $y_{N}$ denote, respectively, the value of domestic production of traded and nontraded goods, and $n_{T}$ and $n_{N}$ correspond to employment in each of the two sectors. Demand for labor from each sector is inversely related to that sector's product wage:

$$
n_{T}^{d}=n_{T}^{d}(\omega), \quad n_{N}^{d}=n_{N}^{d}(z \omega), \quad n_{T}^{d \prime}, n_{N}^{d \prime}<0,
$$

where $\omega=w / P_{T}$ is the real wage in terms of traded goods. Substituting (43) in (42) yields the sectoral supply functions:

$$
y_{T}^{s}=y_{T}^{s}(\omega), \quad y_{N}^{s}=y_{N}^{s}(z \omega), \quad y_{T}^{s \prime}, y_{N}^{s \prime}<0
$$

Domestic demand for traded and nontraded goods is taken to depend on the relative prices of the two goods, given by the real exchange rate, and on total domestic absorption measured in terms of traded goods, $a$, given by

$$
a=a_{T}+z^{-1} a_{N}
$$

Thus, ${ }^{22}$

$$
a_{T}=a_{T}(\bar{z}, \stackrel{+}{a}), \quad 0<\partial a_{T} / \partial a<1
$$

\footnotetext{
${ }^{22}$ As with the previous model, real absorption is taken as exogenous here for expository purposes. For a fully specified dependent economy model, see Montiel (1985), Buiter (1988), and Brock and Turnovsky (1994).
} 


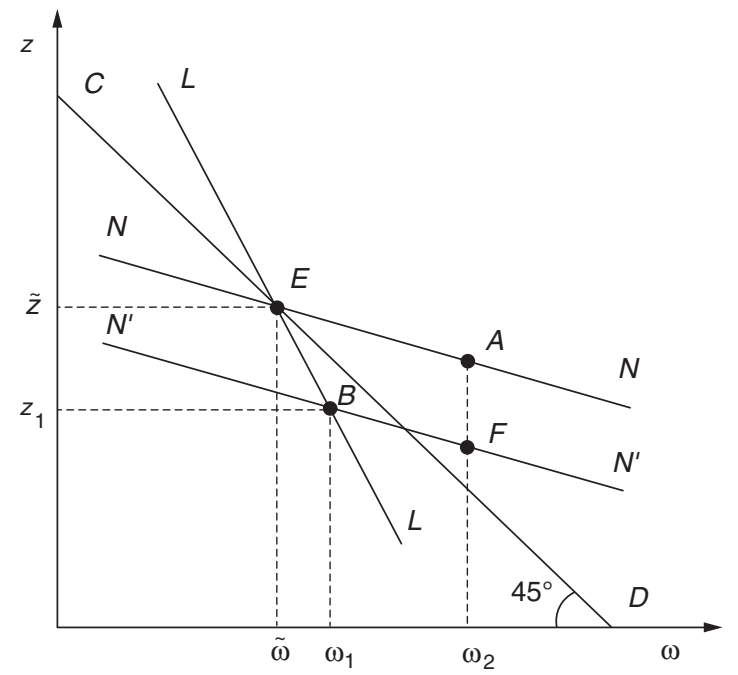

Figure 1-2 - Classical Equilibrium in the Dependent-Economy Model

$$
a_{N}=a_{N}(\stackrel{+}{z}, \stackrel{+}{a}), \quad 0<\partial a_{N} / \partial a=1-\partial a_{T} / \partial a<1 .
$$

The trade balance $b$ is determined by the value of the domestic excess supply of traded goods:

$$
b=y_{T}^{s}(\omega)-a_{T}(z, a)
$$

Equilibrium in the nontraded goods market requires

$$
y_{N}^{s}(z \omega)=a_{N}(z, a)
$$

Finally, the labor market-clearing condition is given by

$$
n_{T}^{d}(\omega)+n_{N}^{d}(z \omega)=\bar{n}
$$

Unlike the Mundell-Fleming model, the classical version of this model is not recursive. Rather than determining the real exchange rate first, and from that the real wage, the real exchange rate and the real wage must be solved together from conditions (49) and (50): that is, the equilibrium values of $\omega$ and $z$ are those that simultaneously clear the labor and nontraded goods markets. The solution is portrayed graphically in Figure 1-2. The locus $L L$ depicts the set of combinations of $\omega$ and $z$ that satisfy the labor market equilibrium condition (50), and $N N$ is the corresponding locus for the nontraded goods market (49). The slope of $L L$ 
(C) Copyright, Princeton University Press. No part of this book may be distributed, posted, or reproduced in any form by digital or mechanical means without prior written permission of the publisher.

is $-\left(n_{N}^{d^{\prime}}+n_{T}^{d^{\prime \prime}}\right) / n_{N}^{d^{\prime}}<-1$, and that of $N N$ is $-y_{N}^{s \prime} n_{N}^{d^{\prime}} /\left(y_{N}^{s \prime} n_{N}^{d^{\prime \prime}}-\partial a_{N} / \partial z\right)>-1$ which, although greater than -1 , is negative. ${ }^{23}$ The line $C D$, with slope -1 , is inserted in the figure for reference. To the right (left) of $L L$, the real wage is too high (low), and excess supply (demand) prevails in the labor market. Similarly, below (above) $N N$ the real exchange rate is excessively appreciated (depreciated), and excess supply (demand) prevails in the market for nontraded goods. The equilibrium combination of $z$ and $\omega$ is given by $(\tilde{z}, \tilde{\omega})$, where $L L$ and $N N$ intersect (point $E$ ).

Consider now the effects of an increase in absorption, $a$. The nontraded goods locus $N N$ shifts down to a position like $N^{\prime} N^{\prime}$, because equilibrium in this market requires a more appreciated real exchange rate when aggregate spending is higher. The new equilibrium moves to $B$, with an appreciated real exchange rate and an increase in the real wage. Notice that, because $B$ lies below $C D$, the proportional reduction in $z$ exceeds the proportional increase in $\omega$. This means that the product wage in the nontraded goods sector falls. Thus, labor is released from the traded goods sector and absorbed by the nontraded goods sector. For this reason, and because the appreciation of the real exchange rate shifts demand toward the traded good, the trade balance deteriorates.

The graphical analysis of the determination of internal and external balance can be conducted in a manner similar to that of the Mundell-Fleming model by solving (50) for $\omega$ in terms of $z$. The slope of this relationship is that of the $L L$ locus in Figure 1-2-it is negative and greater than unity in absolute value. Substituting the resulting expression into (48) and (49) yields a pair of equations that determine the trade surplus and the nontraded goods market equilibrium as functions of $z$ and $a$, in the manner of Figure 1-1.

The Keynesian form of this model takes $\omega$ to be exogenous. In Figure 1-2, if the initial value of $\omega$ is $\omega_{2}$, the market for nontraded goods will clear at point $A$, and the labor market will be characterized by a situation of excess supply, because point $A$ is to the right of $L L$. An increase in $a$ would move the economy to point $F$, which would reduce the extent of excess supply in the labor market since the nontraded goods sector would expand, in this case not by drawing labor away from the traded goods sector but rather by absorbing unemployed workers. The analysis of internal and external balance in this case can use (49) and (50) as they are, treating $\omega$ as given. Because a nominal devaluation would alter $\omega$, it would cause shifts in the Keynesian version of both (49) and (50) in $z$-a space.

\subsection{A Model with Three Goods}

The dependent economy model incorporates an important developing-country stylized fact described earlier-the exogeneity in the terms of trade-but it does not capture another feature of such economies also mentioned previously: variability in

\footnotetext{
${ }^{23}$ Both slopes are calculated around initial values $z=\omega=1$.
} 
(c) Copyright, Princeton University Press. No part of this book may be distributed, posted, or reproduced in any form by digital or mechanical means without prior written permission of the publisher.

the terms of trade as a source of macroeconomic shocks. It does not do so, of course, because to aggregate exportables and importables into a composite good means that the terms of trade are taken as fixed. Allowing changes in the terms of trade, then, requires disaggregating the traded goods sector into separate exportables (identified with the symbol $X$ ) and importables sectors (symbol $I$ ); that is, it requires the use of a three-good model.

In this subsection we examine a simple version of such a model, one in which the exportable good is not consumed at home. This assumption would represent a reasonable approximation to reality in an economy whose exports are dominated by a primary commodity. As suggested earlier, despite an increase in the relative importance of manufactured goods in recent years, this continues to be the case in many developing countries.

In the three-good model, production takes place in three sectors, with sectoral production functions given by

$$
y_{b}=y_{b}\left(n_{b}\right), \quad y_{b}^{\prime}>0, y_{b}^{\prime \prime}<0, \quad b=X, I, N .
$$

Labor demand is given by

$$
n_{X}^{d}=n_{X}^{d}\left(\omega \Theta^{-1}\right), \quad n_{I}^{d}=n_{I}^{d}(\omega), n_{N}^{d}=n_{N}^{d}(z \omega),
$$

with $n_{b}^{d^{\prime}}<0$. In this equation $\Theta$ denotes the terms of trade, given by $P_{X} / P_{I} ; z$ the real exchange rate measured in terms of importables, so that $z \equiv P_{I} / P_{N}$; and $\omega$ the real wage in terms of importables. $P_{X}, P_{I}$, and $P_{N}$ represent the domestic-currency prices of exportables, importables, and nontraded goods, respectively. The first two are given by the law of one price, so that $P_{X}=E P_{X}^{*}$ and $P_{I}=E P_{I}^{*}$. By contrast, $P_{N}$ is determined domestically.

In general, changes in the terms of trade can be expected to have sectoral resource reallocation effects on the supply side of the economy, of the type already seen in our discussion of the dependent economy model. In addition, however, because terms-oftrade changes affect a country's real income, they can be expected to have demandside effects as well. To incorporate these effects in the simplest possible fashion, we shall assume that domestic absorption measured in terms of importables, denoted $a$, is given by

$$
a=a(\stackrel{+}{\Theta}, \stackrel{+}{g})
$$

Thus, absorption depends positively on the terms of trade as well as on the shift parameter $g$. As in the previous section, sectoral supply functions can be derived by substituting the sectoral labor demand functions given in (52) into the sectoral production functions in (51). Equilibrium in the market for nontraded 


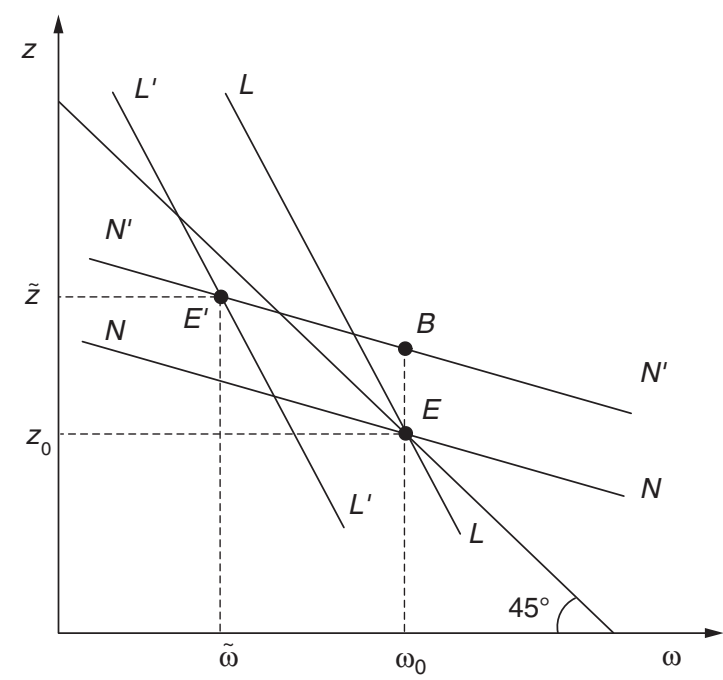

Figure 1-3 - Effects of a Negative Terms-of-Trade Shock in the Three-Good Model

goods requires

$$
y_{N}(z \omega)=a_{N}(\stackrel{+}{z}, \stackrel{+}{a}), \quad 0<\partial a_{N} / \partial a<1
$$

The trade surplus measured in units of importables $b$ is given by the domestic excess supply of traded goods:

$$
b=\Theta y_{X}\left(\omega \Theta^{-1}\right)+y_{I}(\omega)-a_{I}(z, a) .
$$

Finally, the full employment condition is

$$
n_{X}^{d}\left(\omega \Theta^{-1}\right)+n_{I}^{d}(\omega)+n_{N}^{d}(z \omega)=\bar{n}
$$

Like the others, this model can be analyzed in the classical or Keynesian mode. For a given value of the terms of trade, the analysis exactly duplicates that of the dependent-economy model and will not be repeated here. What distinguishes this model from the previous ones, however, is its ability to handle changes in the terms of trade. Accordingly, the rest of this section examines the effects of terms-of-trade changes on the real exchange rate and the real wage in the three-good model. In the classical mode, these variables are determined simultaneously by (54) and (56). The diagrammatic apparatus is presented in Figure 1-3, where the curves $N N$ and $L L$ depict (54) and (56), respectively, and the determination of equilibrium at point $E$ is exactly as in Figure 1-2. 
(c) Copyright, Princeton University Press. No part of this book may be distributed, posted, or reproduced in any form by digital or mechanical means without prior written permission of the publisher.

Consider now a deterioration in the terms of trade brought about by a reduction in $P_{X}$. In this case, $\Theta$ falls on impact. From (53), absorption also falls. This means that the real exchange rate must depreciate to maintain equilibrium in the market for nontraded goods; that is, the $N N$ locus shifts up in Figure 1-3, to $N^{\prime} N^{\prime}$. At the same time, the product wage rises in the exportables sector, inducing this sector to shed labor as it contracts production. To maintain full employment at a given value of $\omega$, the excess labor must be absorbed by the nontraded goods sector. This can happen only if $z$ falls, so $L L$ shifts down. The outcome, as shown in Figure 1-3, is a new equilibrium with a depreciated real exchange rate and reduced real wage, at point $E^{\prime}$.

In the Keynesian case, the real wage in terms of importables cannot change. Thus, the new equilibrium is at point $B$, rather than $E^{\prime}$. The situation is characterized by unemployed labor, since point $B$ lies to the right of the labor market equilibrium locus $L^{\prime} L^{\prime}$. The real exchange rate depreciation in the Keynesian case is less than that in the classical case. To maintain full employment under Keynesian conditions requires a nominal devaluation that would reduce the real wage from $\omega$ to $\tilde{\omega}$, thus moving the economy from point $B$ to point $E^{\prime}$ along $N^{\prime} N^{\prime}$.

An important application of the model described in this section is to the "Dutch disease" phenomenon, which refers to the macroeconomic implications of the existence of a booming sector. ${ }^{24} \mathrm{~A}$ "boom" in the present context can be represented by the reverse of the shock just analyzed, that is, an increase in $P_{X}$. In this case, the real exchange rate would appreciate ( $z$ would fall), and as a consequence $\omega$ would rise. The result would be a contraction of output in the importables sector. Because this outcome arises in part due to the larger spending on nontradables induced by the favorable income effects associated with the terms-of-trade shock, it will be more pronounced the larger such effects are. In developing countries, the "Dutch disease" phenomenon has often been aggravated by expansionary macroeconomic policy responses to favorable terms-of-trade shocks. Such responses have proved difficult to reverse when the shocks that induced them proved to be transitory.

\section{The Structure of Labor Markets}

The study of labor markets in development economics focuses traditionally on medium- and long-run issues, such as the determinants of rural-to-urban migration, the growth in the urban labor force and the associated rise in unemployment, and the effects of education on levels of earnings. Some contributions have recognized the crucial role that the structure of labor markets may play in determining the effects of trade reforms and structural adjustment policies. ${ }^{25}$ However, labor markets also

\footnotetext{
${ }^{24}$ The term "Dutch disease" arose out of concern about de-industrialization in the Netherlands as a result of North Sea oil discoveries. A comprehensive survey of the literature on this issue is provided by Corden (1984).

${ }^{25}$ See, for instance, Edwards (1988), who emphasizes the role of labor reallocation across sectors.
} 
(C) Copyright, Princeton University Press. No part of this book may be distributed, posted, or reproduced in any form by digital or mechanical means without prior written permission of the publisher.

play an important role in the transmission of macroeconomic policy shocks. The different effects of policy and external shocks in the classical and Keynesian versions of the models analyzed in the previous section, for instance, are entirely attributable to differing assumptions about the degree of nominal wage flexibility. More generally, the degree of wage inertia determines to a large extent the effect of fiscal, monetary, and exchange-rate policies on real output. In particular, as will be shown in Chapter 9, real wage resistance plays an important role in determining whether or not a nominal devaluation is contractionary. The purpose of this section is to examine the main empirical characteristics of labor markets in developing countries and highlight their macroeconomic implications, with a particular emphasis on the short-term determination of wages and the nature of labor market segmentation. We begin by outlining some structural features of these markets. We then examine the correlation among output, wages, and unemployment. We conclude by discussing the nature and sources of labor market segmentation in developing countries.

\subsection{Functioning of Labor Markets}

Labor markets in developing nations differ in important ways from those operating in industrial countries. Key structural differences are the importance of the agricultural sector in economic activity (which implies that employment tends to display a marked seasonal pattern), the importance of self-employment, and irregular work activities. These structural differences imply that standard labor market concepts used in the industrial world (such as employment and unemployment) do not necessarily have the same meaning here and must be interpreted with care.

Development economists typically distinguish three sectors in the labor market in developing countries (see Agénor, 2006b). The first is the rural sector, which is characterized by a large share of self-employed persons and unpaid family workers. The second segment is the informal urban sector, characterized by self-employed individuals or small, privately owned enterprises producing mainly services and other nontradables. Activities in this sector rely mostly on the provision of labor services by owners and their families, but occasionally also on paid labor without any formal employment contract. Job insecurity is pervasive, wages are highly flexible, and workers get very few benefits from their employers. Legal minimum wage laws do not apply or are not enforced, and labor unions play a very limited role. The third segment of the labor market is the formal urban sector, consisting of medium and large enterprises (including state-owned firms) that hire workers on the basis of formal contracts. Workers and employers are subject to various labor market regulations. Employers, in particular, must provide a variety of benefits (such as a pension plan, health insurance, and relative job security) to their workers. ${ }^{26}$ Labor unions often

\footnotetext{
${ }^{26}$ In some countries, the formal sector is not entirely confined to urban areas; wage earners bound by explicit contracts may also be employed in agriculture.
} 
(C) Copyright, Princeton University Press. No part of this book may be distributed, posted, or reproduced in any form by digital or mechanical means without prior written permission of the publisher.

play an important role in the determination of wages, and legal minimum wage laws exist, albeit enforced with varying stringency across professions and countries.

A number of studies have attempted to identify the determinants of the size of the formal and informal sectors. Dabla-Norris et al. (2008) develop a general equilibrium model where the quality of the legal system (or the likelihood of detecting informal activity) manifests itself not only in better access to government-provided services, as in some other studies, but in enforcing better compliance with existing entry regulations. In particular, better legal quality implies a higher probability of detection of informal entrepreneurs who avoid entry regulation requirements, such as licensing fees and compliance with labor standards. Their cross-country regressions, based on firm-level data, highlight the importance of the quality of the legal system in explaining the size of the informal sector. ${ }^{27}$ An important aspect of legal quality relates to the incidence of credit market imperfections, as measured by the cost of enforcement of financial contracts. Numerical experiments performed by Antunes and Cavalcanti (2007) suggest that these costs can be as important as regulation costs in explaining the size of the informal sector in developing countries.

Along the same line, Straub (2005) argued that the benefits of being formal can be viewed as consisting of access to two categories of public goods. First, those making production possible (as, for instance, police and judicial protection against crime) and/or enhancing productivity (such as public infrastructure). Second, those which, by ensuring the enforcement of property rights and contracts, secure access to specific markets, where they make interactions between private agents possible and more efficient. The effect of the second category of public goods is of particular importance in the credit market. His analysis shows that the decision of an entrepreneur to become formal or not depends on the amount of available initial capital (which affects the ability to pledge collateral), the relative efficiency of credit markets (as measured by the ability to recover loans through the judiciary), and the cost of registering formally. Other factors include the volatility of the economic environment and the existence of labor rigidities (such as minimum wage requirements or dismissal costs).

In many developing countries, agriculture still employs the great majority of the labor force in rural areas, and the "modern" sector is small. The functioning of rural and urban labor markets differs considerably in at least three respects. First, the heterogeneity and diversity of production in urban areas requires a wider variety of competence and skills among workers. Second, seasonal and climatic effects on production in urban areas are less pronounced than in rural areas. Third, urban production activities are more concentrated geographically than in rural agriculture.

\footnotetext{
${ }^{27}$ Auriol and Warlters (2005) suggest that high barriers to entry to the formal sector may be consistent with a deliberate government strategy for raising tax revenue. By generating market power, and hence rents, for the permitted entrants, market entry fees foster the emergence of large taxpayers. The rents can then be confiscated by the government through entry fees and taxes on profits. However, this view presumes that confiscation can occur at a low administrative cost - which is at variance with much of the evidence on tax collection costs in these countries (see Bird and Zolt, 2005).
} 
(c) Copyright, Princeton University Press. No part of this book may be distributed, posted, or reproduced in any form by digital or mechanical means without prior written permission of the publisher.

As a result of the importance of the rural and urban informal sectors, the proportion of wage earners in total employment tends to be much lower than in the industrial world, although there are large variations across countries and regions. Wage employment (which tends to be positively correlated with the urbanization rate and the size of the public sector) accounts for about 10 percent of total employment in some low-income Sub-Saharan African countries, but as much as 80 percent in some middle-income Latin American countries. The share of informal sector employment in total urban employment is sizable in many developing countries-particularly in some parts of Asia, the Middle East, and Sub-Saharan Africa-and may vary between 40 and 60 percent (Agénor, 2006 b; and Schneider, 2011).

\section{2 - Open and Disguised Unemployment}

Available data on employment and unemployment in developing countries are not very reliable and often are not comparable across nations. ${ }^{28}$ Another problem is that published measures of unemployment are based mostly on unemployed workers looking for jobs in the formal sector, and do not include underemployed workers in the informal and rural sectors-the so-called disguised unemployment. The effective excess supply of labor may thus be understated. In addition, open unemployment may show a rising trend despite strong employment growth, as industrialization combined with migration from rural to urban sectors frequently means that previously underemployed workers are registered as openly unemployed while they are looking for industrial jobs. The available evidence suggests, in fact, that underemployment is far more pervasive than open unemployment. In some countries, open and disguised unemployment vary anywhere from 25 to 60 percent of the labor force (Agénor, 2006b).

Data on the rate of output growth and the measured unemployment rate for developing countries indicate in some cases a relatively close inverse correlation for some countries, but also a rather weak relationship for others, and the correlation seems to vary erratically over time. The absence of a stable "Okun's law" (see for instance Blanchard and Fischer, 1989, pp. 8-9) may be the result of spillover effects across different segments of the labor market, as discussed below.

\subsection{Indexation and Wage Rigidity}

From a macroeconomic perspective, a critical aspect of the functioning of labor markets is the degree of real wage rigidity. In developing countries, a variety of labor

\footnotetext{
${ }^{28}$ Most estimates are derived from labor force surveys and, less frequently, general censuses of population. The International Labor Office has devoted considerable effort to establishing adequate measures of unemployment in developing countries.
} 
(C) Copyright, Princeton University Press. No part of this book may be distributed, posted, or reproduced in any form by digital or mechanical means without prior written permission of the publisher.

market regulations-minimum wages, indexation laws, employment-protecting measures such as labor tenure laws, restrictions on labor mobility, governmentimposed taxes, and large, powerful trade unions - may inhibit real and nominal wage flexibility. ${ }^{29}$ Although the relative importance of these factors varies considerably across regions, countries, and over time, an endemic feature has been implicit or explicit wage indexation. In high-inflation countries in particular, wage indexation is an essential feature of the labor market.

Indexation clauses, under normal circumstances, allow for adjustment of wages for productivity changes as well as past inflation. Procedures differ among countries and over time in three main respects: the interval between wage adjustments, the degree of indexation to inflation, and the nature of adjustments for productivity changes. In some countries, the law permits the productivity adjustment to be negotiated freely between workers and employers; in others, the adjustments are specified by the government. In some countries, the frequency of wage adjustments has tended to increase with the rate of inflation; many economists view the frequency itself as one of the structural elements in the inflationary process (see Dornbusch et al., 1990; Simonsen, 1983; and Parkin, 1991). In some cases the degree of indexation to inflation is a function of the wage level, with over-indexation at certain wage levels and under-indexation at others. The average degree of indexation has also been used as a means of altering inflationary expectations and reducing the inertial element in inflation, as was the case in Argentina (see Online Supplement B).

The manner in which indexation operates is important for the transmission of policy shocks to output, inflation, and unemployment. The traditional view of indexation suggests that it helps to insulate output and employment from monetary (demand) shocks, but not from real (supply) shocks. ${ }^{30}$ A high degree of real wage rigidity would therefore insulate the real sector from aggregate demand shocks. However, a high degree of wage indexing at the sectoral level may also distort policy-induced price signals, such as a nominal devaluation, and may hamper the reallocation of resources. Moreover, indexed contracts are often viewed as the root cause of inflation persistence and stickiness of inflationary expectations. Institutional reforms aimed at reducing the degree of indexation of wages may thus be a critical component for ensuring the credibility and ultimate success of disinflation programs (see Chapter 11).

Despite the widespread existence of wage indexation, however, real wages in many countries seem to be more flexible than is generally assumed. Horton et al. (1994), in particular, summarize the findings of a large World Bank study on labor

\footnotetext{
${ }^{29}$ Labor unions, for instance, have long been viewed as the main culprits in explanations of wage rigidity in Latin America. Over the past few years, institutional reforms in some countries have greatly reduced their bargaining power and ability to impose wage settlements on employers.

${ }^{30}$ See Blanchard and Fischer (1989, pp. 523-25). Carmichael et al. (1985) provide a detailed discussion of wage indexation rules in an open-economy context. Most of the analytical literature assumes the existence of ex ante indexation. In practice, wage indexation is generally ex post, with the current wage adjusting to past changes in prices. Fischer (1988) examines the role of ex post wage indexation in the conduct of disinflation programs.
} 
(C) Copyright, Princeton University Press. No part of this book may be distributed, posted, or reproduced in any form by digital or mechanical means without prior written permission of the publisher.

markets and adjustment in developing countries that provides quantitative evidence supporting the existence of a relatively high degree of real wage flexibility in Latin America and Asia; Agénor (2006b) reviews further evidence along these lines. The persistence of unemployment in many cases, therefore, cannot be attributed to excessive real wage rigidity but may result from aggregate demand effects associated with declining real wages and output market imperfections. The first type of effect is known as the Keynes-Kalecki effect (Taylor, 1991). It relies on the assumption that the propensity to save is considerably lower for wage earners than for profit recipients. To the extent that a fall in real wages is accompanied by a fall in the share of wages in national income, aggregate demand will also fall. Unemployment may therefore persist despite a substantial reduction in real wages. The second type of effect may occur as a result of imperfect competition in product markets, even if labor markets are competitive and real wages flexible (Layard et al., 1991). Unfortunately, empirical attempts at discriminating between these alternative hypotheses are scarce.

Although the prevalence of real wage rigidity may be questionable, there is a widespread consensus that nominal wage rigidity is a pervasive feature of the labor market in many developing countries. Nominal wage inertia results from a variety of factors, including lagged indexation, staggered and overlapping wage contracts, and slow adjustment in inflationary expectations. The existence of multiperiod labor contracts appears to be the prevalent source of nominal wage rigidity in some middleincome countries. We will develop a formal specification of nominal wage contracts that captures both backward-and forward-looking indexation rules in Chapter 11.

\subsection{Labor Market Segmentation}

Labor market dualism in developing countries may be related to the sector of employment or the production structure (agriculture and industry, or traditional and modern), the geographic location of activities (rural and urban, as indicated earlier), the legal nature of activities (formal and informal), or the composition of the labor force (skilled and unskilled workers). These disaggregations do not in general correspond to the distinctions discussed earlier between tradable and nontradable sectors or to the three-good production framework, but may prove useful for macroeconomic analysis. This is because a frequent implication of dualism is labor market segmentation, which can be defined as a situation where observationally identical workers receive different wages depending on their sector of employment. In particular, restrictions on occupational mobility between sectors-resulting from institutional barriers or other factors-may prevent workers in the "low-wage" segment from having full access to a job in the "high-wage" segment held by workers with similar qualifications, even if wages are fully flexible. If there were no barriers, workers in the low-wage sector would enter the high-wage sector and bid wages down in that sector, until sectoral earnings were equalized. Labor market segmentation may 
(c) Copyright, Princeton University Press. No part of this book may be distributed, posted, or reproduced in any form by digital or mechanical means without prior written permission of the publisher.

also be induced by the existence of sectoral wage rigidities, which lead to demandconstrained employment.

The best-known model of labor market segmentation in developing nations is the migration model of Harris and Todaro (1970). The main objective of the model is to explain the persistence of rural-to-urban migration, despite the existence of widespread urban unemployment in developing countries. A key element of the model is the equality of expected (rather than actual) wages as the basic equilibrium condition across the different segments of the labor market. Specifically, Harris and Todaro assume that rural workers, in deciding to migrate, compare the current wage in agriculture $w_{A}$ to the expected urban wage $w_{U}^{a}$, which is calculated by multiplying the prevailing wage $w_{U}$-assumed fixed as a result of, say, minimum wage legislation - by the urban employment ratio, which measures the probability of being hired. In equilibrium, the Harris-Todaro hypothesis yields

$$
w_{A}=w_{U}^{a}=w_{U} \frac{n_{U}}{n_{U}+L_{U}}
$$

where $n_{U}$ is urban employment and $L_{U}$ the absolute number of workers unemployed in urban areas. The Harris-Todaro model has been extended in a variety of directions over the years (see Agénor, 2006b). Particularly interesting developments have been the explanation of urban wage rigidity as a result of efficiency considerations rather than government regulations. According to these hypotheses, real wage cuts lower productivity because they directly reduce incentives to provide effort (Stiglitz, 1982), raise incentives to shirk, increase the quit rate (and thus turnover costs, as emphasized by Stiglitz, 1974), and reduce loyalty to the firm. For instance, workers' effort may depend positively on the wage paid in the current sector of employment (say, the urban sector), relative to the wage paid in other production sectors (the agricultural wage) or the reservation wage. In such conditions each firm will set its wage so as to minimize labor costs per efficiency unit, rather than labor costs per worker. The wage that minimizes labor costs per efficiency unit is known as the efficiency wage. The firm hires labor up to the point where its marginal revenue product is equal to the real wage it has set. A typical case, then, is that aggregate demand for labor, when each firm offers its efficiency wage, falls short of labor supply, so that involuntary unemployment emerges. ${ }^{31}$ Efficiency wage theories are particularly useful for explaining why modern-sector firms pay more than the market-clearing wage in models with segmented labor markets. They predict the existence of noncompetitive wage differentials even in the absence of unions and other institutional constraints.

The importance of accounting for market segmentation and the degree of wage flexibility for a proper understanding of the effects of macroeconomic shocks on unemployment can be illustrated with a simple graphical analysis. Consider a small

\footnotetext{
${ }^{31}$ There is a voluminous literature on developed countries that views involuntary unemployment as the result of efficiency wages. See Blanchard and Fischer (1989) and Layard et al. (1991).
} 

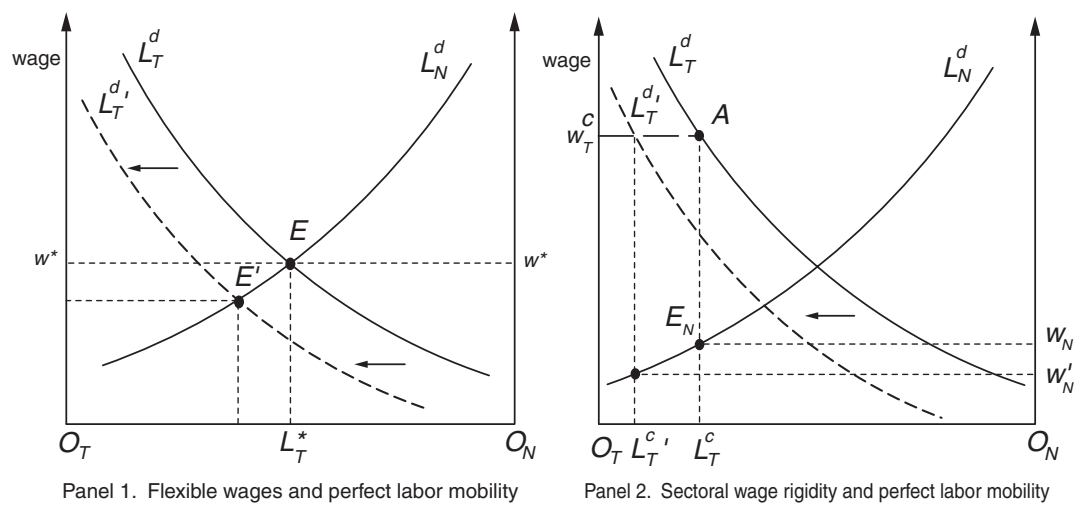

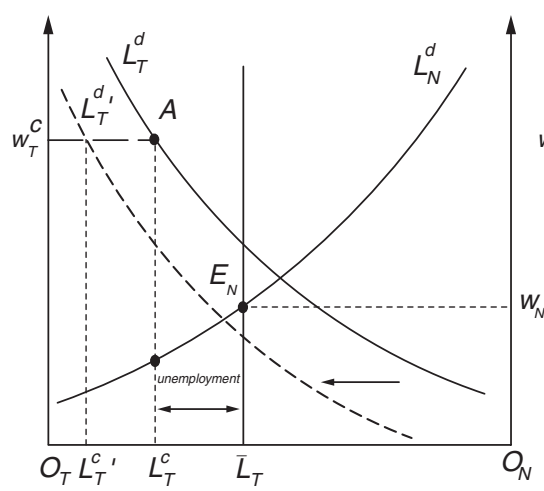

Panel 3. Sectoral wage rigidity and no labor mobility

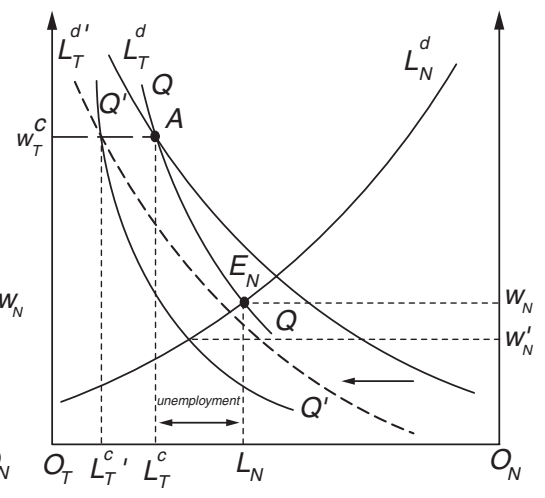

Panel 4. Harris-Todaro migration process

Figure 1-4 - Labor Mobility, Sectoral Wage Rigidity, and Adjustment

open economy producing traded and nontraded goods using only labor, the supply of which is given. The determination of wages and employment under four different assumptions regarding labor market adjustment is shown in Figure 1-4. In all four panels the horizontal axis measures total labor available to the economy, $O_{T} O_{N}$. The vertical axis measures the wage rate in the economy, which is either uniform across sectors or sector-specific. The demand for labor in the traded (nontraded) goods sector is represented by the downward-sloping curve $L_{T}^{d}\left(L_{N}^{d}\right)$. Consider first panel 1, which is based on the assumption that wages are perfectly flexible and labor perfectly mobile across sectors. The initial equilibrium position of the labor market obtains at point $E$, where the economy-wide wage rate is equal to $w^{*}$, labor employed in the traded goods sector is $O_{T} L_{T}^{*}$, and labor used in the production of nontraded goods is $L_{T}^{*} O_{N}$.

In panels 2, 3, and 4, the wage rate in the traded goods sector is fixed at $w_{T}^{c}$ (above the economy-wide, market-clearing wage) whereas wages in the nontraded 
(C) Copyright, Princeton University Press. No part of this book may be distributed, posted, or reproduced in any form by digital or mechanical means without prior written permission of the publisher.

goods sector remain flexible. ${ }^{32}$ The panels differ in the underlying assumptions regarding the degree of intersectoral labor mobility. In panel 2, labor can move freely across sectors, as in panel 1 . Perfect labor mobility, together with wage flexibility in the nontraded goods sector, prevents the emergence of unemployment. The initial equilibrium obtains at point $A$ in the traded goods sector, corresponding to an employment level of $O_{T} L_{T}^{c}$, and at point $E_{N}$ in the nontraded goods sector, with wages equal to $w_{N}$ and employment to $L_{T}^{c} O_{N}$. In panel 3, labor is completely immobile within the time frame of the analysis. The labor force in the traded goods sector is equal to $O_{T} \bar{L}_{T}$, while the supply of labor in the nontraded goods sector is measured by $\bar{L}_{T} O_{N}$. Since sectoral labor supply is completely inelastic and wages cannot adjust in the traded goods sector, unemployment will typically emerge in that sector. The situation depicted in panel 3 indicates that employment in the traded goods sector is equal to $O_{T} L_{T}^{c}$ and unemployment to $L_{T}^{c} \bar{L}_{T}$. Finally, panel 4 is an adaptation of the Harris-Todaro labor allocation mechanism, which assumes that equilibrium obtains when the wage rate in the nontraded goods sector is equal to the expected wage in the traded goods sector. The downward-sloping locus $Q Q$ is a rectangular hyperbola along which this equality holds, and is known as the HarrisTodaro curve (Corden and Findlay, 1975). ${ }^{33}$ The intersection of the $L_{N}^{d}$ curve with QQ determines the wage rate and the employment level in the nontraded goods sector, while the intersection of the $L_{T}^{d}$ curve with the horizontal line drawn at $w_{T}^{c}$ determines employment in the traded goods sector. The initial equilibrium is therefore also characterized by sectoral unemployment, which is equal to $L_{T}^{c} L_{N}$.

Suppose that the demand for labor in the traded goods sector falls, as a result of a macroeconomic shock - a reduction, say, in sectoral productivity—shifting the curve $L_{T}^{d}$ to the left, while leaving the demand curve for labor in the nontraded goods sector unchanged. Let us also abstract, in this partial-equilibrium analysis, from induced effects of the shock on relative prices, income, and wealth. If wages are perfectly flexible and labor perfectly mobile across sectors, adjustment of the labor market leads to a fall in the overall wage rate in the economy and a reallocation of labor across sectors, leading the economy to a new equilibrium (point $E^{\prime}$ in panel 1 ) with full employment.

Consider now what happens in the presence of a sector-specific wage rigidity. If labor is perfectly mobile across sectors, the demand shock leads only to a reallocation of the labor force and a fall in wages in the nontraded goods sector (panel 2).

\footnotetext{
${ }^{32}$ The source of wage rigidity in the traded goods sector is deliberately left unspecified at this stage. A common rationale is the existence of a government-imposed minimum wage, which typically covers only the manufacturing sector. A different interpretation is provided in the general equilibrium model presented below.

${ }^{33}$ As indicated above, the expected wage in the traded goods sector is defined as the product of the actual wage in that sector times the probability of being hired, which is measured by the employment ratio: $w_{T}\left(L_{T}^{d} / O_{T} \bar{L}_{T}\right)$. The equilibrium condition of the Harris-Todaro model implies, therefore, that $w_{N}\left(O_{T} \bar{L}_{T}\right)=w_{T} L_{T}^{d}$. Since $L_{T}^{d}$ is a decreasing function of $w_{T}$ in general, the preceding condition defines the rectangular hyperbola $Q Q$. The requirement that wage rates be equal to the marginal product of labor for $w_{T}=w_{T}^{c}$ is met only at points $A$ and $E_{N}$ on the $Q Q$ curve.
} 
(C) Copyright, Princeton University Press. No part of this book may be distributed, posted, or reproduced in any form by digital or mechanical means without prior written permission of the publisher.

However, if workers cannot move across sectors, the reduction in demand leads to an increase in unemployment in the traded goods sector, with no effect on wages and employment in the nontraded goods sector (panel 3). With a labor allocation mechanism of the Harris-Todaro type, the shock reduces employment in the traded goods sector, as in the preceding case. However, the effect on the unemployment rate is now ambiguous. This is because the $Q Q$ curve shifts to the left following the shift in $L_{T}^{d}$ since the fall in employment reduces the likelihood of being hired and, therefore, the expected wage in the traded goods sector. This implies that more workers would elect to seek employment in the nontraded goods sector, bidding wages down. Employment therefore increases in the nontraded goods sector, while wages fall. However, despite the reallocation of labor across sectors, in equilibrium unemployment may well increase in the traded goods sector. The thrust of the analysis, therefore, is that it is critically important to assess correctly the key features of the labor market in order to evaluate the implications of macroeconomic shocks on wages, employment, and the unemployment rate in the economy. ${ }^{34} \mathrm{We}$ will examine in Chapter 4 how labor market segmentation and relative wage rigidity induced by efficiency considerations alter the transmission of macroeconomic policy shocks.

An additional implication of labor market segmentation is that it offers a particularly clear interpretation of the apparent instability (discussed earlier) of Okun's law in developing countries. Agénor and Aizenman (1999a) provide an analytical framework, which is discussed in more detail in Chapter 4, that helps explain the mechanisms at work. Essentially, their analysis stresses the possibility that interactions between the formal and informal urban labor markets may be characterized by substitutability rather than complementarity in the short run, implying that the employment effects of macroeconomic policy shocks can be highly mitigated. In periods of weak output growth, for instance, skilled as well as unskilled workers laid off in the formal sector may seek employment in the informal sector where wages and labor productivity tend to be lower. Unless skilled workers' reservation wage is higher than the going wage for unskilled workers in the informal sector (as a result, for instance, of generous unemployment benefits in the formal sector), fluctuations in aggregate demand will translate into changes in average productivity rather than a rise in open unemployment.

\footnotetext{
${ }^{34}$ Note that the existence of unemployment in the situation depicted in panel 3 may be only a short-run phenomenon, if labor can adjust over time, so that the long-run outcome might be similar to that which obtains in panel 2.
} 